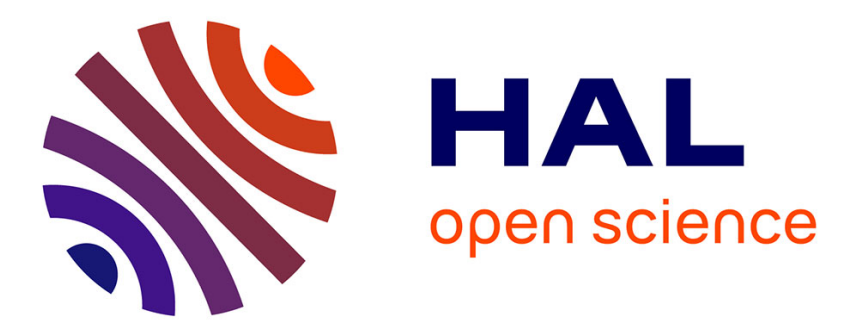

\title{
Experimental evidence of Xe incorporation in Schottky defects in UO_2
}

René Bes, Philippe Martin, Emerson Vathonne, Rémy Delorme, Catherine Sabathier, Michel Freyss, M. Bertolus, Pieter Glatzel

\section{- To cite this version:}

René Bes, Philippe Martin, Emerson Vathonne, Rémy Delorme, Catherine Sabathier, et al.. Experimental evidence of Xe incorporation in Schottky defects in UO_2. Applied Physics Letters, 2015, 106, pp.114102. 10.1063/1.2644500UO2 . cea-02066511

\section{HAL Id: cea-02066511 https://hal-cea.archives-ouvertes.fr/cea-02066511}

Submitted on 13 Mar 2019

HAL is a multi-disciplinary open access archive for the deposit and dissemination of scientific research documents, whether they are published or not. The documents may come from teaching and research institutions in France or abroad, or from public or private research centers.
L'archive ouverte pluridisciplinaire HAL, est destinée au dépôt et à la diffusion de documents scientifiques de niveau recherche, publiés ou non, émanant des établissements d'enseignement et de recherche français ou étrangers, des laboratoires publics ou privés. 


\section{A|P Applied Physics Letters}

\section{Experimental evidence of Xe incorporation in Schottky defects in UO2}

René Bès, Philippe Martin, Emerson Vathonne, Rémy Delorme, Catherine Sabathier, Michel Freyss, Marjorie

Bertolus, and Pieter Glatzel

Citation: Applied Physics Letters 106, 114102 (2015); doi: 10.1063/1.4914300

View online: http://dx.doi.org/10.1063/1.4914300

View Table of Contents: http://scitation.aip.org/content/aip/journal/apl/106/11?ver=pdfcov

Published by the AIP Publishing

\section{Articles you may be interested in}

Lattice thermal conductivity of UO2 using ab-initio and classical molecular dynamics

J. Appl. Phys. 115, 123510 (2014); 10.1063/1.4869669

First principles modeling of zirconium solution in bulk $\mathrm{UO} 2$

J. Appl. Phys. 113, 183514 (2013); 10.1063/1.4803849

Photoelectron spectroscopy and the electronic structure of the uranyl tetrachloride dianion: $\mathrm{UO} 2 \mathrm{Cl} 42-$

J. Chem. Phys. 137, 064315 (2012); 10.1063/1.4742062

Biogenic UO2 - Characterization and Surface Reactivity

AIP Conf. Proc. 882, 277 (2007); 10.1063/1.2644500

UO2 (111) Single Crystal: Comparison of Stoichiometric and Defective Surfaces by XPS

Surf. Sci. Spectra 13, 72 (2006); 10.1116/11.20050601

\section{Model PS-100}

Tabletop Cryogenic Probe Station
Lake Shore CRYOTRONICS
An affordable solution for a wide range of research 


\title{
Experimental evidence of Xe incorporation in Schottky defects in $\mathrm{UO}_{2}$
}

\author{
René Bès, ${ }^{1,2, a)}$ Philippe Martin, ${ }^{1, b)}$ Emerson Vathonne, ${ }^{1}$ Rémy Delorme, ${ }^{1}$ \\ Catherine Sabathier, ${ }^{1}$ Michel Freyss, ${ }^{1}$ Marjorie Bertolus, ${ }^{1}$ and Pieter Glatzel ${ }^{3}$ \\ ${ }^{1}$ CEA, DEN, DEC, F-13108 Saint Paul Lez Durance Cedex, France \\ ${ }^{2}$ Synchrotron SOLEIL, Ligne de Lumière MARS, L'Ormes des Merisiers, Saint Aubin, BP48, \\ F-91192 Gif-sur-Yvette Cedex, France \\ ${ }^{3}$ European Synchrotron Radiation Facility (ESRF), 6 Rue Jules Horowitz, BP 220, 38043 Grenoble Cedex 9 , \\ France
}

(Received 5 January 2015; accepted 25 February 2015; published online 16 March 2015)

\begin{abstract}
We report here the direct experimental observation of the preferential xenon incorporation site in uranium dioxide and analyse how its incorporation evolves with the annealing temperature. We show that High Energy Resolution Fluorescence Detection X-ray Absorption Near Edge Structure in combination with first-principles calculations enable a precise determination of the Xe incorporation site. Our finding provides important insight for the understanding and modeling of noble gases behavior in nuclear oxide fuel. (C) 2015 AIP Publishing LLC.
\end{abstract}

[http://dx.doi.org/10.1063/1.4914300]

Rare gas behavior in materials has been at the heart of great research efforts for decades and cover many scientific domains such as geochemistry and planetary sciences, ${ }^{1}$ medicine, ${ }^{2}$ and nuclear applications. ${ }^{3}$ Due to their insolubility in solids and their chemical inertness, noble gases can conveniently be used as a probe for chemical, physical, and structural changes in a wide range of materials as glasses, ${ }^{4}$ semiconductors and metals, ${ }^{5}$ as well as ceramics. ${ }^{6}$ In particular, xenon can be used to investigate the microporosity distribution in materials. $^{7}$

In the uranium dioxide nuclear fuel $\left(\mathrm{UO}_{2}\right)$, xenon is an abundant fission product. Due to their high insolubility in $\mathrm{UO}_{2},{ }^{8}$ xenon atoms coalesce into bubbles, inducing swelling and degradation of the material properties. ${ }^{9,10}$ The good understanding of the behavior of this gaseous fission product is mandatory for a safety-oriented control of the nuclear fuel evolution under nominal and transient conditions. One of the main difficulties to model xenon behavior in materials lies in predicting the ratio between xenon atoms isolated in the matrix and the ones forming nano-aggregates. The latter strongly influence the migration kinetics by trapping $\mathrm{Xe}$ atoms and affect their diffusion coefficient currently used in nuclear fuel performance codes. ${ }^{11}$ Beyond the nuclear material interest, solid state chemistry modeling of gaseous incorporation in materials requires a complete evaluation of the pressure and the density of gas bubbles but also of the incorporation site of the isolated gas atom. Indeed, the knowledge of both the migration and coalescence of xenon as a function of in operando parameters, such as temperature, xenon concentration, or defect types, would increase our understanding of the crystal lattice dynamics separately from any chemistry.

A large amount of literature has been dedicated to experimental studies of xenon properties in nuclear fuels. ${ }^{12-20}$ Most of the experimental studies however are limited to its precipitation to form bubbles and by the need of sufficient gas concentration to extract valuable experimental signal.

\footnotetext{
a)rene.bes@cea.fr

b) philippe-m.martin@cea.fr
}

Due to the difficulty to probe experimentally diluted impurities (less than 0.5 at. \%) in a heavy matrix like $\mathrm{UO}_{2}$, the xenon behavior (incorporation sites, pathways, and energetics of its migration) in $\mathrm{UO}_{2}$ have been determined only using both density functional theory (DFT) $)^{21-30}$ and empirical potentials. ${ }^{11,26,29-38}$ The incorporation site and diffusion mechanisms have not unambiguously determined even if authors generally agree with the fact that due to steric constraints, vacancy trap sites are favored over interstitial sites. However, no clear experimental evidence has been provided yet. An efficient technique to obtain data about atomic ordering is X-ray Absorption Spectroscopy as it gives information about the local environment of one specific element diluted in a matrix. For example, by coupling Transmitted Electron Microscopy (TEM) observations and X-ray Absorption Spectroscopy (XAS) experiments at the xenon $\mathrm{K}$-edge, the presence of highly pressurized (around $3 \mathrm{GPa}$ ) nanometer size bubbles in $\mathrm{UO}_{2}$ has been recently demonstrated. ${ }^{39,40}$ Most of the literature results have been obtained at relatively high concentration (some at. \%), for which the formation of coarse bubbles was strongly expected. To ensure direct comparison with irradiated fuel, the concentration of Xe should have been 5 times less, but remains experimentally difficult to analyze because of the low signal over noise ratio.

In the past few years, the development of X-ray emission spectrometers on beamlines of synchrotron sources has allowed the study of highly diluted materials by High Energy Resolution Fluorescence Detection Spectroscopy (HERFD-XAS), which is a combination of XAS and X-ray Emission Spectroscopy (XES). This experimental approach increases drastically the signal over noise ratio, opening the door for the study of xenon at concentration encountered in irradiated nuclear fuels. However, the XAS interpretation is, in general, not straightforward. Spectra modeling remain a very useful tool to this aim. But XAS modeling codes require as input crystallographic data. This data can be derived from calculations such as electronic structure calculations (for instance, using DFT method). 
Samples were depleted $\mathrm{UO}_{2}$ polycrystalline $\left({ }^{235} \mathrm{U}\right.$ isotopic content of about $0.3 \%$ of total uranium) discs cut from sintered pellets (density about $98 \%$ of theoretical density). They were first polished and annealed $4 \mathrm{~h}$ at $1673 \mathrm{~K}$ in a reducing atmosphere of $\mathrm{Ar}+5 \% \mathrm{H}_{2}$. They were then implanted with Xe ion at room temperature using the implantor at CSNSM laboratory (Orsay, France). The ${ }^{129} \mathrm{Xe}^{2+} \mathrm{im}-$ plantation beam had an energy of $390 \mathrm{keV}$ at normal incidence and the fluence was $1.7 \times 10^{15} \mathrm{~cm}^{-2}$. Considering a theoretical volumic mass of $10.96 \mathrm{~g} \mathrm{~cm}^{-3}$, these conditions correspond to an ion projected depth of $71 \mathrm{~nm}$ (FWHM of $75 \mathrm{~nm}$ ) as evaluated using the SRIM code. ${ }^{41}$ The maximal concentration is about 0.37 at. \%. Two samples were annealed under a reducing atmosphere $\left(\mathrm{Ar}+5 \% \mathrm{H}_{2}\right)$ during $12 \mathrm{~h}$ at $873 \mathrm{~K}$ and $4 \mathrm{~h}$ at $1673 \mathrm{~K}$ accordingly to the standard in pile and rapid power transient temperatures, respectively, measured in the intermediate pellet region of light water reactor irradiated fuel.

The $\mathrm{Xe}_{3}$-edge spectra were collected in fluorescence mode at the European Synchrotron Radiation Facility (ESRF, Grenoble, France) on the ID26 beamline using a wavelength dispersive crystal emission spectrometer. ${ }^{42,43}$ Spectra were recorded in a continuous quick scan mode of both monochromator and undulator gap over the energy range. The spot size of the incident X-ray beam on the sample was $0.2 \times 1 \mathrm{~mm}^{2}$. Higher harmonics were rejected by three Si mirrors operating in total reflection. High energy resolution fluorescence detection was achieved by employing four spherically bent $\mathrm{Si}$ crystals (bending radius $1000 \mathrm{~mm}$ ) with a (311) orientation in Rowland geometry. The incident energy was calibrated using a Ti foil (K-edge energy tabulated at $4966 \mathrm{eV})$. The emission spectrometer was tuned to the $\mathrm{L}_{3} \mathrm{M}_{5}\left(\mathrm{~L} \alpha_{1}\right.$ or $\left.3 \mathrm{~d}_{5 / 2}-2 \mathrm{p}_{3 / 2}\right)$ emission line of $\mathrm{Xe}$ at $4109.6 \mathrm{eV}$. The paths of the incident and emitted X-rays through air were minimized in order to avoid undesirable absorption.

XAS spectra were systematically collected at $15 \mathrm{~K}$ using a He cryostat and at room temperature in order to be alternatively below and above the Xe melting point temperature of $110 \mathrm{~K}$. The ATHENA software ${ }^{44}$ was used for normalizing XANES spectra using linear functions for both pre-edge removal and post-edge normalization. The first maximum of the spectrum first energy derivative was used to determine the edge position $\mathrm{E}_{0}$.

Figure 1 shows the HERFD-XANES spectra collected at room temperature and at $15 \mathrm{~K}$.

The absorption spectra of the as-implanted and $873 \mathrm{~K}$ annealed samples are similar and characterized by a weak resonance at $4786 \mathrm{eV}$. Two broad intense peaks are also located around $4791 \mathrm{eV}$ and $4794 \mathrm{eV}$, and are followed by a very broadened weak oscillation around $4808 \mathrm{eV}$. The annealing at $873 \mathrm{~K}$ causes only a slight evolution of the HERFD spectra compared to the as-implanted one. A $1 \mathrm{eV}$ shift of the first broad peak at $4790 \mathrm{eV}$ is measured in this case. As a consequence, small modifications of the geometry around xenon atoms are expected. Moreover, the thermal energy available during annealing at $873 \mathrm{~K}$ was insufficient to overcome the large diffusion barrier inducing Xe to be trapped. A strong resonance, the so-called white line, is present at $4786 \mathrm{eV}$ on the HERFD spectra of the sample annealed

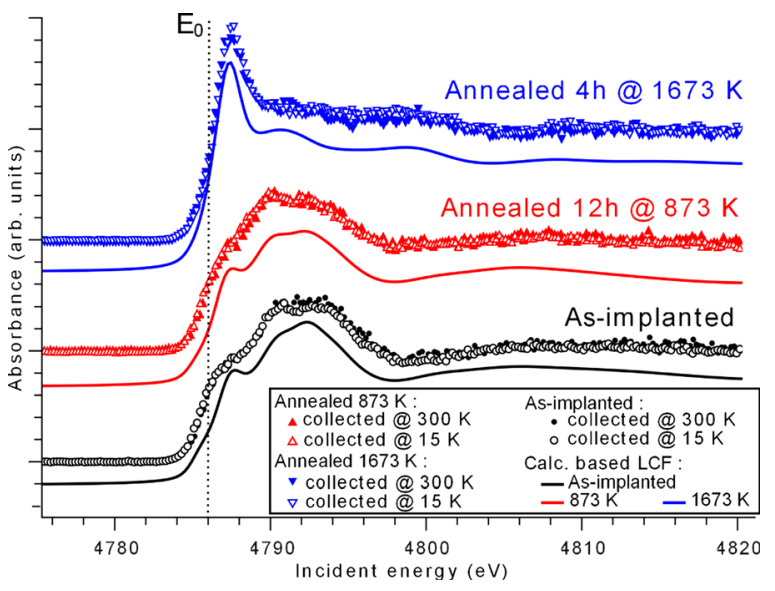

FIG. 1. HERFD-XANES spectra (symbols) and their best fit (line) using $\mathrm{LCF}$ at the $\mathrm{Xe} \mathrm{L}_{3}$ edge of as-implanted and annealed samples collected at room temperature (filled symbols) and at $15 \mathrm{~K}$ (open symbols). Dashed line indicates the energy position of the $\mathrm{E}_{0}$ value. Spectra were vertically shifted for sake of clarity.

at $1673 \mathrm{~K}$. Two slight oscillations with maxima located at $4791 \mathrm{eV}$ and $4798 \mathrm{eV}$ can be also observed on this spectra. At $1673 \mathrm{~K}$, the width and shape of the absorption spectrum are very different compared to those observed on both the as-implanted and $873 \mathrm{~K}$ annealed samples. This is the sign of significant changes in the local environment of xenon atoms and a probable enhance mobility of these atoms. Finally, no significant change is noticed after cooling the sample from $300 \mathrm{~K}$ to $15 \mathrm{~K}$. This indicates that $\mathrm{Xe}$ could not be in liquid or gaseous phase as the xenon melting point is $110 \mathrm{~K}$. Consequently, the local environment of xenon atoms should consist of highly pressurized clusters and/or isolated atoms in the $\mathrm{UO}_{2}$ fluorite structure.

To evaluate the local environment corresponding to these absorption spectra, XANES spectra were modeled using the FDMNES code. ${ }^{45}$ These calculations were based on static atom supercells of hundred atoms and thermally induced disorder was not considered. The final states and resulting absorption cross sections were calculated using the muffin-tin approximation. ${ }^{45}$ The impact of the muffin-tin approximation compared to finite difference method has been evaluated and can be neglected in our case. Due to the presence of heavy nuclei ( $\mathrm{U}$ and $\mathrm{Xe}$ ), spin-orbit effects were taken into account in the calculations. In HERFD-XANES, the width of the spectral features is no longer limited by the $2 \mathrm{p}_{3 / 2}\left(\mathrm{~L}_{3}\right.$ shell) core-hole lifetime $(3.01 \mathrm{eV})$ but by the sharper $3 \mathrm{~d}_{5 / 2}\left(\mathrm{M}_{5}\right.$ shell) core-hole width $(0.72 \mathrm{eV})$ in the final state. ${ }^{43}$ The atomic coordinates used as input file for FDMNES calculations were derived from first-principles DFT $+U$ optimized structure for Xe isolated atoms in $\mathrm{UO}_{2}$ and determined using the $F m \overline{3} m$ (225) crystallographic structure of solid xenon ${ }^{46}$ for Xe bubbles.

The DFT calculations were performed in the periodic boundary conditions formalism using 96 atom supercell. The same parameters as those used in reference. ${ }^{47}$ We have considered the incorporation of $\mathrm{Xe}$ in various positions in the $\mathrm{UO}_{2}$ lattice such as octahedral interstitial (noted $\mathrm{I}_{X e}$ ), $\mathrm{U}$ and $\mathrm{O}$ mono-vacancies (noted $\mathrm{V}_{U}$ and $\mathrm{V}_{O}$, respectively), and the Schottky defects. For the latter, the three possible orientations of the two oxygen divacancies, i.e., along the (100), 
(110), and (111) directions, have been considered (noted as $\mathrm{SD}(100), \mathrm{SD}(110)$, and $\mathrm{SD}(111)$, respectively).

The pressurized bubbles XANES spectra were modeled by using the cell parameter of Xe solid crystal compressed up to $15 \%$ (i.e., from 6.13 to $5.23 \AA$ ). In the following, they were noted as $\mathrm{PB}(\mathrm{X} \%)$, where $\mathrm{X}$ is the compression ratio of the cell parameter. The reference spectra, calculated with the structure optimized using DFT $+U$ and with the Xe crystal structure, are reported in Figure 2. In order to take into account, the broadening due to disorder (from temperature and implantation process) and the energy resolution, all of the calculated spectra were convoluted with a Gaussian of $0.4 \mathrm{eV}$ width before fitting.

The Xe crystal calculated spectra present a strong resonance at $4786 \mathrm{eV}$ and two slight oscillations with maxima located around $4791 \mathrm{eV}$ and $4798 \mathrm{eV}$. By increasing the pressure, the two oscillations are shifted to high energy. The calculated spectra of xenon incorporated in the $\mathrm{UO}_{2}$ matrix have a weak resonance peak at $4786 \mathrm{eV}$ and a broader, more intense feature around $4792 \mathrm{eV}$ depending on the considered incorporation site. As the local environment of Xe atoms is quite similar for U vacancy and the three Schottky defects from the U sublattice point of view, the corresponding calculated spectra present strong similarities. Consequently, up to now, it has only been possible to discriminate the Xe interstitial site, the oxygen vacancy, and the xenon bubbles signals.

The fit of the experimental absorption spectra reported in Figure 1 was performed using Linear Combination Fitting (LCF) of the reference spectra, as implemented in the ATHENA software.

The best fits show that Xe is mainly located on a mix of uranium vacancy, Schottky defects, and pressurized bubbles, excluding oxygen vacancy, as reported in Table I.

The experimental spectra of the as-implanted and $873 \mathrm{~K}$ annealed samples are mainly composed of uranium vacancy and Schottky defects oriented along (100) and (111) directions. The concentration of the latter as well as the apparent trapping of Xe into an interstitial site of about $16 \% \pm 2 \%$ is quite surprising as in our DFT $+U$ calculations, these

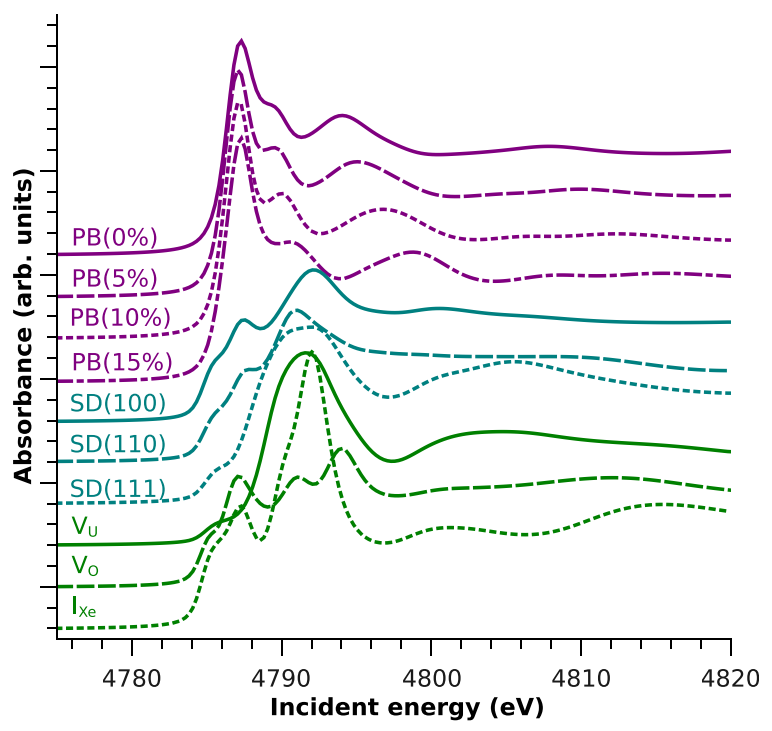

FIG. 2. Reference spectra calculated with FDMNES code ${ }^{45}$ by using atomic position from DFT $+U$ calculations and from solid Xe crystal properties.
TABLE I. Best fits derived value of the Xe local environment as a function of the samples. The values given here have been derived from the data collected at $15 \mathrm{~K}$.

\begin{tabular}{lccc}
\hline \hline $\begin{array}{l}\text { Local } \\
\text { environment }\end{array}$ & $\begin{array}{c}\text { As-implanted } \\
\text { sample }\end{array}$ & $\begin{array}{c}\text { Annealed } \\
12 \mathrm{~h} \text { at } 873 \mathrm{~K}\end{array}$ & $\begin{array}{c}\text { Annealed } \\
4 \mathrm{~h} \text { at } 1673 \mathrm{~K}\end{array}$ \\
\hline $\mathrm{I}_{X e}$ & $16_{-2}^{+2} \%$ & $16_{-1}^{+1} \%$ & $1_{-1}^{+1} \%$ \\
$\mathrm{~V}_{U}$ & $9_{-4}^{+4} \%$ & $9_{-5}^{+5} \%$ & $2_{-2}^{+2} \%$ \\
$\mathrm{~V}_{O}$ & $1_{-1}^{+1} \%$ & $1_{-1}^{+1} \%$ & $1_{-1}^{+1} \%$ \\
$\mathrm{SD}(100)$ & $17_{-7}^{+7} \%$ & $17_{-7}^{+7} \%$ & $23_{-6}^{+6} \%$ \\
$\mathrm{SD}(110)$ & $9_{-7}^{+7} \%$ & $9_{-8}^{+8} \%$ & $3_{-3}^{+4} \%$ \\
$\mathrm{SD}(111)$ & $18_{-5}^{+5} \%$ & $18_{-5}^{+5} \%$ & $2_{-2}^{+3} \%$ \\
$\mathrm{~PB}(0 \%)$ & $20_{-10}^{+10} \%$ & $20_{-10}^{+10} \%$ & $5_{-5}^{+8} \%$ \\
$\mathrm{~PB}(5 \%)$ & $12_{-9}^{+9} \%$ & $12_{-10}^{+10} \%$ & $12_{-11}^{+11} \%$ \\
$\mathrm{~PB}(10 \%)$ & $5_{-5}^{+5} \%$ & $5_{-5}^{+5} \%$ & $5_{-4}^{+4} \%$ \\
$\mathrm{~PB}(15 \%)$ & $4_{-4}^{+4} \%$ & $4_{-4}^{+3} \%$ & $60_{-6}^{+6} \%$ \\
$\mathrm{R}-$ factor & 0.0091 & 0.0084 & 0.0075 \\
\hline \hline
\end{tabular}

incorporation sites were strongly unfavored as compared to $\mathrm{SD}(100) .{ }^{48}$ Such incorporations are probably the consequence of the structural disorder induced by the ion implantation process and not completely annealed at $873 \mathrm{~K}$. Moreover, the high concentration of $\mathrm{SD}(111)$ can be considered as additional uranium vacancy percentage as the $\mathrm{V}_{U}$ and $\mathrm{SD}(111)$ spectra are very similar due to the identical geometry of first neighboring uranium atoms. Finally, the complement involves Xe weakly pressurized bubbles, for which the solid Xe cell parameter is at least compressed by about $5 \%$ (i.e., local density of Xe about $2.02 \times 10^{22} \mathrm{Xe} \mathrm{cm}^{-3}$ ).

After annealing at $1673 \mathrm{~K}$, Xe atoms diffuse and coalesce to form highly pressurized bubbles as illustrated by a solid Xe cell parameter compressed of about $15 \%$. This compression corresponds to a local Xe density of about $2.80 \times 10^{22}$ atoms $\mathrm{cm}^{-3}$. The signal of these dense aggregates corresponds to about $60 \%$ of the experimental spectrum. The remaining percent of Xe has been found for $20 \%$ in low pressurized bubbles and for 23\% in the Schottky defects with the two oxygen vacancies aligned along (100) direction. The latter is in agreement with our DFT $+U$ calculations showing that this incorporation site is especially favored as compared to U vacancy and Schottky defects with oxygen vacancies aligned along (110) and (111) directions ${ }^{48}$ in agreement with earlier studies. ${ }^{49,50}$ Moreover, the concentrations of $U$ vacancy and $\mathrm{SD}(111)$ tends to confirm that the local disorder is completely annealed at $1673 \mathrm{~K}$.

We have thus presented here experimental evidence of the Xe incorporation in Schottky defects in $\mathrm{UO}_{2}$ using an advanced approach to probe directly isolated atoms. We have shown that the experimental results of high energy resolution

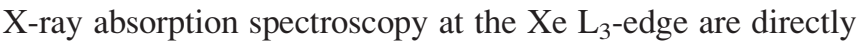
comparable to electronic structure calculations. Further experiments and calculations are in progress to extend the discrimination of local environment in U vacancy and Schottky defects (from the U sublattice point of view). The method described in this paper can be performed on other species in materials and should be widely applied in the future.

Authors acknowledge the European Synchrotron Radiation Facility for providing beamtime, and also acknowledge Y. Joly for stimulating discussion about XANES simulation. 
${ }^{1}$ C. Sanloup, B. C. Schmidt, G. Gudfinnsson, A. Dewaele, and M. Mezouar, Geochim. Cosmochim. Acta 75, 6271 (2011).

${ }^{2}$ F. C. Marques, P. F. Barbieri, G. A. Viana, and D. S. da Silva, Appl. Surf. Sci. 275, 156 (2013).

${ }^{3}$ C. Degueldre, M. Pouchon, M. Döbeli, K. Sickafus, K. Hojou, G. Ledergerber, and S. Abolhassani-Dadras, J. Nucl. Mater. 289, 115 (2001).

${ }^{4}$ R. Bès, T. Sauvage, S. Peuget, J. Haussy, F. Chamssedine, E. Oliviero, T. Fares, and L. Vincent, J. Nucl. Mater. 443, 544 (2013).

${ }^{5}$ H. J. Matzke, Thermochim. Acta 190, 31 (1991).

${ }^{6}$ R. Bès, Y. Pipon, N. Millard-Pinard, S. Gavarini, and M. Freyss, Phys. Rev. B 87, 024104 (2013).

${ }^{7}$ S. V. Filimonova, H. Knicker, W. Häusler, and I. Kögel-Knabner, Geoderma 122, 25 (2004)

${ }^{8}$ G. Brillant, F. Gupta, and A. Pasturel, J. Nucl. Mater. 412, 170 (2011).

${ }^{9}$ J. A. Turnbull, J. Nucl. Mater. 38, 203 (1971).

${ }^{10}$ R. J. White, OECD Report HPR-368, 2008.

${ }^{11}$ K. Govers, S. Lemehov, and M. Verwerft, J. Nucl. Mater. 374, 461 (2008).

${ }^{12}$ R. Lindner and H. J. Matzke, Z. Naturforsch., A: Phys. Sci. 14, 582 (1959), available at: http://zfn.mpdl.mpg.de/data/Reihe_A/14/ZNA-195914a-0582_n.pdf.

${ }^{13}$ W. Miekeley and F. W. Felix, J. Nucl. Mater. 42, 297 (1972).

${ }^{14}$ H. J. Matzke, Radiat. Eff. Defects Solids 53, 219 (1980).

${ }^{15}$ H. J. Matzke, in Diffusion Processes in Nuclear Materials, edited by R. P. Agarwala (North-Holland, Amsterdam, 1992).

${ }^{16} \mathrm{G}$. Sattonnay, L. Vincent, F. Garrido, and L. Thomé, J. Nucl. Mater. 355, 131 (2006).

${ }^{17}$ H. Kim, K. Park, Y. Yun, B. G. Kim, H. J. Ryu, K. C. Song, Y. S. Choo, and K. P. Hong, Ann. Nucl. Eng. 34, 153 (2007).

${ }^{18}$ C. Sabathier, L. Vincent, P. Garcia, F. Garrido, G. Carlot, L. Thome, and C. Valot, Nucl. Instrum. Methods Phys. Res., Sect. B 266, 3027 (2008).

${ }^{19}$ A. Michel, C. Sabathier, G. Carlot, O. Kaïtasov, S. Bouffard, P. Garcia, and C. Valot, Nucl. Instrum. Methods Phys. Res., Sect. B 272, 218 (2012).

${ }^{20}$ B. Marchand, N. Moncoffre, Y. Pipon, C. Garnier, N. Bérerd, C. Delafoy, M. Fraczkiewicz, A. Perrat-Mabilon, L. Raimbault, P. Sainsot, and N. Toulhoat, Prog. Nucl. Energy 57, 145 (2012).

${ }^{21}$ T. Petit, in Fission Gas Behaviour in Water Reactor Fuels (OECD, Cadarache, France, 2002), p. 269.

${ }^{22}$ M. Freyss, N. Vergnet, and T. Petit, J. Nucl. Mater. 352, 144 (2006).

${ }^{23}$ Y. Yun, H. Kim, and K. Park, J. Nucl. Mater. 378, 40 (2008).

${ }^{24}$ P. V. Nerikar, X.-Y. Liu, B. P. Uberuaga, C. R. Stanek, S. R. Phillpot, and S. B. Sinnot, J. Phys.: Condens. Matter. 21, 435602 (2009).

${ }^{25}$ F. Zhou and V. Ozolins, Phys. Rev. B 80, 125127 (2009).

${ }^{26} \mathrm{P}$. Tiwary, A. van de Walle, B. Jeon, and N. Grønbech-Jensen, Phys. Rev. B 83, 094104 (2011).
${ }^{27}$ B. E. Hanken, C. R. Stanek, N. Grønbech-Jensen, and M. Asta, Phys. Rev. B 84, 085131 (2011)

${ }^{28}$ D. A. Andersson, B. P. Uberuaga, P. V. Nerikar, C. Unal, and C. R. Stanek, Phys. Rev. B 84, 054105 (2011).

${ }^{29}$ X.-Y. Liu, B. P. Uberuaga, D. A. Andersson, C. R. Stanek, and K. E. Sickafus, Appl. Phys. Lett. 98, 151902 (2011).

${ }^{30}$ A. E. Thompson and C. Wolverton, Phys. Rev. B 87, 104105 (2013).

${ }^{31}$ C. R. A. Catlow and R. W. Grimes, J. Nucl. Mater. 165, 313 (1989).

${ }^{32}$ R. W. Grimes, in Fundamental Aspects of Inert Gases in Solids, edited by S. E. Donnelly and H. J. Evans (Springer, New York, 1990), p. 415.

${ }^{33}$ R. G. J. Ball and R. W. Grimes, J. Nucl. Mater. 188, 216 (1992).

${ }^{34}$ S. Nicoll, H. J. Matzke, and C. R. A. Catlow, J. Nucl. Mater. 226, 51 (1995).

${ }^{35}$ C. R. Stanek and R. W. Grimes, J. Nucl. Mater. 282, 265 (2000).

${ }^{36}$ K. Govers, S. Lemehov, M. Hou, and M. Verwerft, J. Nucl. Mater. 376, 66 (2008).

${ }^{37}$ B. Jeon, M. Asta, S. M. Valone, and N. Grønbech-Jensen, Nucl. Instrum. Methods Phys. Res., Sect. B 268, 2688 (2010)

${ }^{38}$ A. Jelea, R. J.-M. Pellenq, and F. Ribeiro, J. Nucl. Mater. 444, 153 (2014).

${ }^{39}$ P. Garcia, P. Martin, G. Carlot, E. Castelier, M. Ripert, C. Sabathier, C. Valot, F. D'Acapito, J.-L. Hazemann, O. Proux, and V. Nassif, J. Nucl. Mater. 352, 136 (2006)

${ }^{40}$ P. Martin, P. Garcia, G. Carlot, C. Sabathier, C. Valot, V. Nassif, O. Proux, and J.-L. Hazemann, Nucl. Instrum. Methods Phys. Res., Sect. B 266, 2887 (2008).

${ }^{41}$ J. F. Ziegler, J. P. Biersack, and M. D. Ziegler, The Stopping and Range of Ions in Matter (2008), see www.SRIM.org.

${ }^{42}$ C. Gauthier, V. A. Solé, R. Signorato, J. Goulon, and E. Moguiline, J. Synchrotron Radiat. 6, 164 (1999).

${ }^{43}$ P. Glatzel, T.-C. Weng, K. Kvashnina, J. Swarbrick, M. Sikora, E. Gallo, N. Smolentsev, and R. A. Mori, J. Electron. Spectrosc. Relat. Phenom. 188, 17 (2013).

${ }^{44}$ B. Ravel and M. Newville, J. Synchrotron Radiat. 12, 537 (2005).

${ }^{45}$ O. Bunau and Y. Joly, J. Phys.: Condens. Matter 21, 345501 (2009).

${ }^{46}$ D. Sears and H. Klug, J. Chem. Phys. 37(2), 3002 (1962).

${ }^{47}$ E. Vathonne, J. Wiktor, M. Freyss, G. Jomard, and M. Bertolus, J. Phys.: Condens. Matter 26, 325501 (2014).

${ }^{48} \mathrm{E}$. Vathonne "Étude par calculs de structure électronique des dégâts d'irradiation dans le combustible nucléaire UO2 : comportement des défauts ponctuels et gaz de fission," Ph.D. Thesis, Aix-Marseille Université (2014).

${ }^{49}$ A. E. Thompson and C. Wolverton, Phys. Rev. B 84, 134111 (2011).

${ }^{50}$ M. Bertolus, M. Freyss, B. Dorado, G. Martin, K. Hoang, S. Maillard, R. Skorek, Ph. Garcia, C. Valot, A. Chartier, L. Van Brutzel, P. Fossati, R. W. Grimes, D. C. Parfitt, C. L. Bishop, S. T. Murphy, M. J. D. Rushton, D. Staicu, E. Yakub, S. Nichenko, M. Krack, F. Devynck, R. Ngayam-Happy, K. Govers, C. S. Deo, and R. K. Behera, J. Nucl. Mater. (published online). 